\title{
ANALISIS KELAYAKAN USAHA BUDIDAYA SELADA KROP DI CV. CANTIGI DESA CIKANDANG KECAMATAN CIKAJANG KABUPATEN GARUT
}

\author{
Anne Rizky Ramadhanty'), Sulistyodewi Nur Wiyono²), Kuswarini Kusno3), \\ dan Lucyana Trimo4) \\ 1)Program Studi Agribisnis, Fakultas Pertanian Universitas Padjadjaran \\ 2, 3,4)Departemen Sosial Ekonomi, Fakultas Pertanian Universitas Padjadjaran \\ Jl. Raya Bandung Sumedang KM.21, Kec. Jatinangor, Kab. Sumedang, Jawa Barat, Indonesia \\ 1)e-mail: annerizky1@gmail.com
}

(Diterima 22 Januari 2020 / Disetujui 10 Februari 2020)

\begin{abstract}
Lettuce head as a vegetable commodity has a high enough business opportunity, seen from the development of hotels and restaurants in Indonesia that serve foreign cuisine using lettuce. The purpose of this study was to determine the feasibility of lettuce head farming in CV.Cantigi. This research was carried out in CV.Cantigi, Cikandang village, Cikajang District, Garut Regency. The design of this research is descriptive quantitative with the research technique is a case study The method of data collection is done by interviews with informants, observations, and literature studies. The determination of the informant was carried out purposive. Analysis of the data used is non-financial feasibility and financial feasibility (Net Present Value, Internal Rate of Return, Net Benefit/Cost Ratio, Payback Period, and Profitability Ratio). The results showed that 1) The income of lettuce head farming in CV.Cantigi in one growing season is IDR 120.821.846; 2) The lettuce head farming in CV. Cantigi is feasible in terms of market aspects, technical aspects, management aspect, and social, economic, cultural and environmental aspects. Similarly, financially, lettuce head farming in CV.Cantigi is feasible to do with an NPV value of IDR 286,076,736.8, IRR 51,87\%, Net B/C Ratio is 4.32, Payback period occurs at 8 years 8 months and profitability ratio of $101.78 \%$. Suggestions for further research there is further research on production technologies that can optimize the use of other production factors to increase production results.
\end{abstract}

Keywords: cv.cantigi, feasibility, lettuce head,

\begin{abstract}
ABSTRAK
Selada krop sebagai komoditas sayuran memiliki peluang bisnis yang cukup tinggi, dilihat dari berkembangnya hotel dan restoran di Indonesia yang menyajikan masakan asing dengan menggunakan lettuce. Tujuan dari penelitian ini adalah untuk mengetahui kendala dan potensi usahatani selada krop, struktur biaya produksi serta kelayakan usahatani selada krop di CV.Cantigi. Penelitian ini dilaksanakan di CV.Cantigi desa Cikandang, Kecamatan Cikajang, Kabupaten Garut. Desain pada penelitian ini ialah kuantitatif deskriptif dengan teknik penelitian ialah studi kasus. Metode pengumpulan data dilakukan dengan wawancara dengan informan, observasi, serta studi literatur. Penentuan informan dilakukan secara sengaja (purposive). Analisis data yang digunakan adalah analisis kelayakan non-finansial dan kelayakan finansial (Net Present Value, Internal Rate Return, Net Benefit/Cost Ratio, Payback Period, dan Profitability Ratio). Hasil penelitian menunjukkan bahwa 1) Pendapatan usahatani selada krop di CV.Cantigi dalam sekali musim tanam yaitu Rp120.821.846; 2) Usahatani selada krop di CV.Cantigi layak dijalankan dilihat berdasarkan aspek pasar, aspek tenik, aspek manajemen, serta aspek sosial, ekonomi, budaya dan lingkungan. Begitu pula secara finansial, usahatani selada krop di CV.Cantigi layak dilakukan dengan nilai NPV Rp286.076.736,8, IRR 51,87\%, Net B/C Ratio 4,32, Payback period terjadi pada 8 tahun 8 bulan dan profitability ratio sebesar $101,78 \%$. Saran untuk penelitian selanjutnya, adanya penelitian lebih lanjut mengenai teknik produksi yang mampu mengoptimalkan penggunaan faktor produksi lainya untuk meningkatkan hasil produksi.
\end{abstract}

Kata Kunci: cv.cantigi, kelayakan, selada krop, 


\section{PENDAHULUAN}

Sub sektor hortikultura memiliki potensi yang cukup baik apabila dikembangkan dengan baik. Pengembangan disini meliputi peningkatan produksi komoditas, peningkatan produktivitas komoditas, ataupun peningkatan teknologi pertanian yang mendukung sejalan dengan perkembangan teknologi saat ini. Sub sektor hortikultura diarahkan untuk mampu meningkatkan kebutuhan konsumsi, bahan baku industri, peningkatan ekspor dan substitusi impor. Berdasarkan Tabel 1, dapat dilihat sejak tahun 2014 hingga tahun 2018, perkembangan ekspor komoditas sayuran pada sub sektor hortikutura mengalami fluktuasi yang cenderung meningkat.

Komoditas hortikultura terdiri atas buahbuahan, sayuran, tanaman hias, dan obat-obatan. Pemilihan sayuran dan buah-buahan guna diusahakan ialah salah satu upaya untuk mempercepat pengembangan perekonomian negara, khususnya pada pedesaan. Komoditas sayuran yang dibahas bukan hanya sayuran lokal, namun juga sayuran impor yang dapat tumbuh di Indonesia. Salah satu komoditas sayuran impor yang berkembang di pasaran ialah sayuran selada. Produksi selada krop (lettuce head) pada tahun 2014 hingga tahun 2015 di Indonesia perkembangannya meningkat 15,64 persen. Diantara beberapa tanaman sayuran lainnya, selada berada pada urutan ketiga tertinggi perkembangannya. Data dapat dilihat pada Tabel 2.

Selada merupakan komoditas sayuran yang belum dimasukkan dalam daftar produksi sayuran nasional. Selada belum termasuk dalam skala prioritas, baik sebagai komoditas utama, potensial ataupun introduksi yang dikembangkan di Indonesia (Rukmana, 1994). Meskipun demikian, prospek ekonomi dari selada ini cukup cerah. Permintaan terhadap selada terus meningkat berdasarkan pada berkembangnya jumlah hotel serta restoran di Indonesia yang menyajikan masakan asing yang menggunakan daun selada. Diantara beberapa provinsi di Indonesia yang mengusahakan budidaya hortikultur, Jawa Barat merupakan provinsi dengan potensi yang cukup besar pada sektor pertanian.

Kabupaten Garut merupakan salah satu daerah penghasil paprika dengan kualitas unggul, adapun tingginya permintaan paprika sebagai sayuran eksklusif mampu meningkatkan permintaan sayuran eksklusif lainnya. Salah satu komoditas sayuran eksklusif lainnya yang dibudidayakan di Kabupaten Garut ialah selada krop.

Selada krop masih tergolong jarang dibudidayakan di Kabupaten Garut. Akan tetapi dilihat berdasarkan kondisi lahan yang memungkinkan untuk pembudidayaan selada krop, menjadikan Kabupaten Garut berpotensi mengembangkan usahatani selada krop. Sehingga saat ini, usahatani selada krop sudah mulai dilakukan namun hanya beberapa pelaku usaha yang telah berpengalaman dalam pembudidayaan sayuran ekslusif yang membudidayakan selada krop tersebut. Salah satu pelaku usaha pertanian yang telah memiliki pengalaman dalam pembudidayaan sayuran ekslusif ialah CV. Cantigi.

Kondisi lahan yang memungkinkan untuk menjalankan usahatani selada krop serta meningkatkan pemintaan selada dengan adanya perkembangan hotel dan restoran yang menyajikan masakan asing yang menggunakan selada menjadikan suatu peluang usaha bagi CV. Cantigi untuk membudidayakan selada krop. Akan tetapi untuk mengetahui seberapa layak usahatani

Tabel 1. Perkembangan Ekspor Non Migas (Sektor) Periode 2014-2018 (Nilai: Juta US\$)

\begin{tabular}{lrrrrr}
\hline \multicolumn{1}{c}{ Sektor } & \multicolumn{5}{c}{ Tahun } \\
\cline { 2 - 6 } & $\mathbf{2 0 1 4}$ & $\mathbf{2 0 1 5}$ & $\mathbf{2 0 1 6}$ & $\mathbf{2 0 1 7}$ & $\mathbf{2 0 1 8}$ \\
\hline Pertanian & & & & & \\
1 Binatang Hidup & 69,6 & 59,1 & 57,3 & 64,0 & 60,9 \\
2 Ikan dan Udang & $2.620,2$ & $2.167,0$ & $2.430,7$ & $2.757,1$ & $1.621,6$ \\
3 Susu, Mentega, Telur & 1,3 & 0,7 & 2,3 & 4,0 & 1,7 \\
4 Produk Hewani & 18,8 & 17,2 & 16,4 & 21,3 & 19,9 \\
5 Pohon Hidup dan Bunga Potong & 21,6 & 30,4 & 20,9 & 17,6 & 18,6 \\
6 Sayuran & 93,3 & 124,5 & 86,3 & 101,4 & 101,8 \\
7 Buah-buahan & 302,1 & 368,6 & 324,1 & 362,3 & 379,5 \\
\hline
\end{tabular}

Sumber: Badan Pusat Statistika (2019) 
Tabel 2. Perkembangan Produksi Beberapa Tanaman Sayuran (Ton) di Indonesia Tahun $2014-2015$

\begin{tabular}{clrrr}
\hline No. & Jenis Sayuran & $\mathbf{2 0 1 4}$ & $\mathbf{2 0 1 5}$ & Perkembangan (\%) \\
\hline 1 & Kembang Kol & 96.038 & 101.205 & 5,38 \\
2 & Paprika & 4.462 & 5.533 & 24,00 \\
3 & Jamur & 38.465 & 61.376 & 59,56 \\
4 & Tomat & 853.061 & 891.616 & 4,52 \\
5 & Terung & 451.654 & 482.305 & 6,81 \\
6 & Selada & 290.993 & 336.494 & 15,64 \\
7 & Ketimun & 583.139 & 547.141 & $-6,17$ \\
8 & Labu Siam & 321.023 & 369.846 & 15,21 \\
9 & Kangkung & 360.992 & 350.879 & $-2,80$ \\
10 & Bayam & 173.750 & 152.334 & $-12,33$ \\
\hline
\end{tabular}

Sumber: Badan Pusat Statistika (2019)

selada krop yang dibudidayakan CV. Cantigi tersebut, diperlukan adanya penelitian terhadap kelayakan dari usahatani selada krop dari segala aspek.

\section{METODE}

\section{LOKASI DAN WAKTU PENELITIAN}

Penelitian dilaksanakan di CV.Cantigi, Desa Cikandang, Kecamatan Cikajang, Kabupaten Garut. Penelitian dilakukan pada bulan November 2019.

\section{METODE ANALISIS DATA}

Penelitian menggunakan desain kuantitatif deskriptif dengan teknik penelitian studi kasus. Penentuan responden dilakukan secara sengaja (purposive), dengan pertimbangan bahwa pemilik dari CV. Cantigi mengetahui seluk beluk perusahaannya, seperti sejarah berdirinya perusahaan, kondisi keuangan, kapasitas produksi dan lainlain yang diharapkan dapat diperoleh hasil yang lebih akurat dan representatif sesuai dengan tujuan yang diharapkan dalam penelitian ini. Data yang dikumpulkan dalam penelitian ini berupa data primer dan data sekunder. Data primer diperoleh dengan cara observasi dan wawancara secara langsung kepada pemilik CV.Cantigi, wawancara dilakukan dengan menggunakan daftar pertanyaan. Sedangkan, data sekunder diperoleh dengan cara observasi literatur yang relevan dengan penelitian ini serta jurnal-jurnal dan instansi yang terkait dengan penelitian ini. Analisis data yang digunakan dalam penelitian ini menggunakan dua pendekatan yaitu analisis pendapatan dan analisis kelayakan usahatani segala aspek.

\section{ANALISIS KELAYAKAN NON-FINANSIAL Aspek Pasar}

Hal-hal yang dianalisis berkaitan dengan aspek pasar ini ialah peluang, potensi pasar, perkembagan harga selada krop, dan gambaran saluran pemasaran selada krop di lokasi penelitian.

\section{Aspek Teknis}

Aspek teknis yang dianalisis dalam penelitian ini ialah keseluruh kegiatan usahatani selada krop. Kegiatan usahatani ini meliputi persiapan budidaya serta faktor-faktor input produksi, kegiatan budidaya, pemeliharaan tanaman, serta penanganan hama dan penyakit.

\section{Aspek Manajemen}

Beberapa faktor yang dianalisis dalam aspek manajemen ialah bentuk organisasi (badan hukum), struktur organisasi, serta sistem upah atau gaji tenaga kerja.

\section{Aspek Sosial, Ekonomi, dan Lingkungan}

Aspek sosial, ekonomi, dan lingkungan dalam penelitian ini ialah kelayakan usaha selada krop dengan mempertimbangkan beberapa faktor sosial, ekonomi, dan lingkungan. Beberapa faktor tersebut meliputi kontribusi usaha selada krop yang dijalankan CV. Cantigi terhadap masyarakat sekitar dalam hal penyerapan tenaga kerja serta penyediaan lapangan pekerjaan, kontribusi terhadap pembangunan dan pendapatan masyarakat 
sekitar, serta dampak dari kegiatan usaha selada krop terhadap lingkungan di lokasi tersebut.

\section{ANALISIS KELAYAKAN FINANSIAL}

Perhitungan NPV dalam suatu penilaian investasi merupakan cara yang praktis dalam mengetahui suatu proyek dapat dikatakan menguntungkan atau tidaknya. Keuntungan suatu proyek merupakan besaran suatu penerimaan dikurangi pembiayaan yang dikeluarkan. Secara matematis NPV dapat dirumuskan sebagai berikut:

$$
N P V=\sum_{t=1}^{n} \frac{B t-C t}{(1+i)^{t}}
$$

Keterangan:

Bt $=$ Benefit pada tahun ke-t

$\mathrm{Ct}=$ Biaya pada tahun ke- $\mathrm{t}$

$\mathrm{t}=$ lamanya waktu investasi

$\mathrm{i}=$ tingkat bunga

NPV > 0 (positif) maka suatu proyek dikatakan menguntungkan, sebaliknya apabila NPV < 0 (negatif) maka suatu proyek dikatakan merugi dan tidak layak untuk diusahakan.

Net Benefit Cost Ratio merupakan penilaian yang dilakukan untuk melihat tingkat efisiensi penggunaan biaya yang berupa perbandingan jumlah nilai bersih sekarang yang positif dengan jumlah nilai bersih sekarang yang negatif.

$$
\begin{gathered}
N e t B / C=\frac{\sum_{t=1}^{n} \frac{B t-C t}{(1+i) t}}{\sum_{t=1}^{n} \frac{C t-B t}{(1+i) t}} \\
N e t B / C=\frac{P V+}{P V-}
\end{gathered}
$$

Usahatani Selada Krop di CV. Cantigi dikatakan layak diusahakan apabila Net B/C Ratio $>1$. Apabila Net B/C Ratio < 1, maka usahatani selada krop tidak layak diusahakan.

Analisis IRR bertujuan untuk mengetahui sejauh mana suatu usaha memberikan manfaat. IRR dinyatakan dalam bentuk persen (\%) yang merupakan tolak ukur keberhasilan suatu usaha (Soekartawi, 1996). Secara matematis IRR dapat dirumuskan sebagai berikut :

$$
\mathrm{IRR}=i_{1}+\frac{N P V_{1}}{N P V_{1}-N P V_{2}}\left(i_{2}-i_{1}\right)
$$

Keterangan :

$\mathrm{NPV}_{1}=$ Perhitungan NPV positif mendekati nol dengan bunga modal sebesar $\mathrm{i}_{1}$ persen

$\mathrm{NPV}_{2}=$ Perhitungan NPV negatif mendekati nol dengan bunga modal sebesar $i_{2}$ persen

$\mathrm{i}_{1}=$ Discount Factor (df) pertama, tingkat bunga yang menghasilkan NPV positif

$\mathrm{i}_{2}=$ Discount Factor (df) kedua, tingkat bunga yang menghasilkan NPV negatif.

Menurut Husnan dan Suwarsono (2000), sebelum dikumulatifkan terlebih dahulu nilai net benefit setiap tahunnya didiskonto sehingga dapat diperoleh present value dari net benefit setiap tahunnya. Semakin kecil nilai yang diperoleh memiliki arti bahwa semakin cepat tingkat pengembalian investasinya, sehingga dapat dikatakan usaha tersebut semakin baik untuk dilaksanakan. Rumus yang digunakan ialah :

$$
\text { Payback Period }=\frac{I}{A b}
$$

Keterangan:

I : Besarnya biaya investasi yang diperlukan

$\mathrm{Ab}$ : Manfaat bersih yang dapat diperoleh pada setiap tahunnya dan telah didiskontokan

Ratio profitability merupakan perbandingan yang menilai kemampuan perusahaan dalam mencari keuntungan (Kasmir, 2014:115). Perbandingan tersebut dapat memberikan tingkat efektivitas manajemen suatu perusahaan. Menurut Ambasari et al. (2014), rumus perhitungan profitability ratio ialah sebagai berikut:

$$
\mathrm{PR}=\frac{\text { Pendapatan }}{\text { Biaya Produksi }} \times 100 \%
$$

Kriteria Pengukuran:

- Profitabilitas > suku bunga deposito, artinya usaha tersebut menguntungkan.

- Profitabilitas < suku bunga deposito, artinya usaha tersebut tidak menguntungkan.

\section{HASIL DAN PEMBAHASAN}

\section{PENERIMAAN USAHATANI SELADA KROP PADA CV.CANTIGI}

Penerimaan dihitung berdasarkan jumlah produksi selada krop setiap periode tanam pada saat luasan lahan 2,5 ha yang dikalikan harga jual 
selada krop. Penerimaan yang diperoleh CV. Cantigi pada komoditas selada krop bukan hanya dari penjualan produk selada krop namun juga dari penjualan bibit selada krop. Maka perhitungan penerimaan CV. Cantigi dalam sekali periode tanam ialah sebagai berikut:

Tabel 3. Penerimaan Usahatani Selada Krop di CV.Cantigi per Satu Musim Tanam

\begin{tabular}{lrrrr}
\hline Produk & Satuan & Jumlah & $\begin{array}{c}\text { Harga } \\
\text { (Rp) }\end{array}$ & \multicolumn{1}{c}{$\begin{array}{c}\text { Penerimaan } \\
\text { (Rp) }\end{array}$} \\
\hline Selada & & & & \\
Krop & Kg & $27.742,67$ & 7.000 & 194.198 .690 \\
Bibit & Pohon & 55.000 & 125 & 6.875 .000 \\
Total Penerimaan & & & 201.073 .690 \\
\hline \multicolumn{2}{l}{ Sumber: Data Primer diolah, 2019}
\end{tabular}

\section{BIAYA USAHATANI}

Pengeluaran usahatani ialah keseluruhan biaya yang dikeluarkan petani atau yang dimaksud dalam penelitian ini ialah CV. Cantigi selama menjalankan usahataninya. Biaya ini dimulai dari biaya awal kegiatan usahatani seperti persiapan lahan, penyediaan benih, penyediaan pupuk, hingga pendistribusian hasil produksi kepada pihak pengepul (buyer). Biaya yang dirincikan ialah biaya usahatani selada krop saat luasan lahan 2,5 ha. Biaya usahatani secara lebih rinci dijelaskan pada Tabel 4 .

Tabel 4. Biaya Usahatani Selada Krop di CV.Cantigi per Periode Tanam

\begin{tabular}{clr}
\hline No & Jenis Biaya & Biaya (Rp) \\
\hline 1 & Tetap & 50.000 .000 \\
& Sewa Lahan & 20.000 .000 \\
& Gaji Tenaga Kerja & 4.791 .844 \\
& Penyusutan & \\
$2 \quad$ Variabel & 1.050 .000 \\
& Bibit Selada Krop & 1.750 .000 \\
& Pupuk Kandang & 277.500 \\
& Pupuk NPK & 1.650 .000 \\
& Mulsa & 532.500 \\
& Pestisida & 200.000 \\
& Bahan Bakar (Bensin) & 80.251 .844 \\
\hline$\quad$ Total Biaya Usahatani
\end{tabular}

Biaya dalam usahatani selada krop ini didominasi oleh biaya sewa lahan dan biaya tenaga kerja. Biaya sewa lahan sangat penting pada kegiatan usahatani selada krop, khususnya yang kegiatan usahataninya dilakukan di lahan terbuka. Adapun biaya tenaga kerja pun sangat penting pada kegiatan usahatani selada krop di CV. Cantigi ini, dikarenakan usahatani tersebut bersifat padat karya. Salah satu cara menekan biaya tenaga kerja melalui penggunaan teknologi produksi yang tepat.

\section{PENDAPATAN USAHATANI SELADA KROP DI CV. CANTIGI}

Pendapatan usahatani mengukur seberapa menguntungkan kegiatan usahatani yang dilakukan dengan membandingkan total penerimaan dengan biaya-biaya yang dikeluarkan selama kegiatan usahatani berlangsung. Pendapatan merupakan pengurangan total biaya terhadap penerimaan. Dimana total biaya terdiri atas biaya tetap dan biaya variabel. Pada penelitian ini pendapatan usahatani selada krop yang dilihat ialah pendapatan usahatani per tahun selama umur usaha. Besarnya pendapatan usahatani yang diperoleh CV. Cantigi dari mengusahakan selada krop dapat dilihat pada Tabel 5.

\section{Tabel 5. Penerimaan, Total Biaya, Pendapatan per Satu Kali Musim Tanam Usahatani Selada Krop di CV. Cantigi}

\begin{tabular}{lr}
\hline \multicolumn{1}{c}{ Komponen } & Akumulasi (Rp) \\
\hline Penerimaan & 201.073 .690 \\
Total Biaya & 80.251 .844 \\
Pendapatan & 120.821 .846 \\
\hline Sumber: Data Primer diolah, 2019 &
\end{tabular}

\section{ANALISIS ASPEK-ASPEK NON FINANSIAL BUDIDAYA SELADA KROP DI CV. CANTIGI Aspek Pasar}

Aspek pasar menjadi suatu aspek yang penting dalam melihat peluang serta potensi pengembangan usahatani, dikarenakan berkaitan dengan permintaan serta penawaran konsumen terhadap produk yang dibutuhkan. Usahatani selada krop yang dijalankan CV. Cantigi sudah cukup dikenal oleh para buyer di kawasan Kabupaten Garut, salah satunya yaitu PT. Lumbung Padi Garut. Dengan adanya kerjasama dengan pihak buyer dapat mempermudah proses pendistribusian produk selada krop itu sendiri serta menjaga kestabilan harga jual produk, karena adanya perjanjian mengenai penentuan harga jual.

Produk selada yang dihasilkan oleh CV. Cantigi ialah produk dengan kualitas yang unggul. 
Pada dasarnya, kualitas yang diproduksi atau dibudidayakan disesuaikan dengan permintaan buyer dan kondisi lahan budidaya. Hal yang utama dalam menjalankan budidaya selada krop ialah pengendalian terhadap tanaman dan pertumbuhannya guna menghasilkan produk dengan kualitas dan kuantitas yang diharapkan.

Harga jual yang ditetapkan sesuai dengan perjanjian yang disepakati bersama, baik dari pihak CV. Cantigi dengan pihak Buyer. Pihak buyer disini ialah PT Lumbung Padi yang membeli hasil panen selada krop dari CV. Cantigi. Harga yang disepakati tergantung pada kondisi pasar yang dituju, jika harga sedang normal pihak CV. Cantigi menjual dengan harga kisaran Rp6.000,00 Rp7.500,00 per kilogram.

Saluran pemasaran yang dilakukan CV. Cantigi ini terdiri dari kebun produksi yang langsung memasarkannya kepada buyer (PT Lumbung Padi). Setelah produk dibeli oleh buyer, produk akan melalui proses grading dan pengemasan dengan merek dagang pihak buyer. Kemudian pihak buyer akan memasarkan produk ke pasar lokal dan juga pasar modern. Lalu, produk akan dijual kembali ke konsumen akhir, baik itu konsumen rumah tangga maupun industri dengan bahan baku selada krop.

Sedangkan, kegiatan promosi yang dilakukan CV. Cantigi pada awal pemasaran selada krop untuk pertama kalinya ialah dengan memberikan sampel secara langsung kepada para buyer atau penampung yang tertarik dengan kualitas produk yang dihasilkan CV. Cantigi. Namun untuk sekarang, promosi sedang tidak dilakukan karena telah menjalin kerjasama dengan buyer tetap untuk memasarkan hasil produksi selada krop itu sendiri.

Berdasarkan analisis diatas, usahatani selada krop dinilai layak untuk dijalankan dikarenakan adanya peluang pasar. Kemudian hasil produksi yang dihasilkan memiliki kualitas yang unggul dan dapat diterima oleh pasar dengan harga jual yang cukup bersaing.

\section{Aspek Teknis}

1. Lokasi Usaha

Ditinjau berdasarkan lokasi usaha dengan akses prasarana untuk memperoleh bahan baku, lokasi pasar yang dituju, tenaga kerja, sarana transportasi, dan tenaga listrik dan air, CV. Cantigi berada pada lokasi yang strategis. Dalam hal memperoleh bahan baku, CV. Cantigi tidak mengalami kesulitan untuk mendapatkannya. Dikarenakan lokasi usaha dengan toko pertanian hanya berjarak 800 meter, namun untuk memperoleh bibit selada krop itu sendiri dirasa masih mengalami sedikit kendala. Hal tersebut dikarenakan tempat penjualan bibit selada krop yang berkualitas unggul baru dipasarkan oleh PT. East West Seed Indonesia yang berletak di Purwakarta. CV. Cantigi dalam mencapai lokasi pasar yang dituju memiliki lokasi usaha yang strategis. Hal tersebut ditunjukkan dengan jarak lokasi usahatani dengan lokasi pasar tidaklah menjadi suatu kendala dalam memasarkan hasil produksinya. Dimana jarak lokasi usahatani dengan lokasi pasar ialah $14 \mathrm{~km}$ yang dapat ditempuh sekitar 30 menit menggunakan mobil.

Kemudian, dalam memperoleh tenaga kerja dan akses transportasi, CV. Cantigi memanfaatkan para masyarakat sekitar lokasi usahatani untuk menjadi tenaga kerjanya. Hal tersebut dilakukan bertujuan agar CV. Cantigi mampu memberdayakan masyarakat sekitar. Sedangkan untuk akses transportasi sudah memadai, dimana jalan sudah beraspal. Adapun pertimbangan lokasi usahatani dengan ketersediaan tenaga listrik dan air sudah memadai. Dalam usahatani selada krop tidak memerlukan banyak tenaga listrik, sehingga ketersediaan tenaga listrik tidaklah menjadi suatu kendala dalam usahatani selada krop. Akan tetapi, usahatani selada krop sangat rentan terhadap ketersediaan air. Sehingga diperlukan perhatian khusus dalam ketersediaan air, untuk di CV. Cantigi sendiri ketersediaan air dapat ditanggulangi dengan penggunaan tong air kapasitas 200 Liter.

\section{Proses Produksi}

Proses produksi yang dilakukan CV. Cantigi dalam membudidayakan selada krop terbilang masih konvensional. Dimana pembudidayaan dilakukan di lahan terbuka dengan membuat bedengan-bedengan yang dilapisi plastik mulsa. Teknik pembudidayaan sudah sesuai 
dengan prosedur operasional Departemen Pertanian. Akan tetapi, untuk jarak tanam yang digunakan CV. Cantigi dalam pembudidayaan selada krop ialah 40 x $80 \mathrm{~cm}$, yang mana jarak tanam tersebut masih dapat disesuaikan dengan jarak tanam ideal agar tetap memperoleh hasil yang optimal dan meningkatkan produktivitasnya. Berdasarkan hasil analisis aspek teknis yang mencakup lokasi usaha dan proses produksi dapat dikatakan bahwa usahatani selada krop layak untuk dijalankan. Lokasi usaha tidak memiliki hambatan serta kendala dalam memperoleh bahan baku, mencapai pasar yang dituju, ketersediaan tenaga listrik dan air, ketersediaan tenaga kerja, prasarana dan fasilitas transportasi, izin pemerintah setempat, serta sikap masyarakat sekitar. Proses produksi pun telah memenuhi standar prosedur operasional selada krop.

\section{Aspek Manajemen}

1. Bentuk Organisasi (Badan Hukum)

Cantigi Utama Farm telah memiliki badan hukum usaha yang berbentuk Comanditaire Vennotschap (CV). Perusahaan yang berbentuk CV ini terdiri atas pihak sekutu aktif dan sekutu pasif. Dalam hal ini pihak yang berperan sebagai sekutu aktif ialah Ir. Risa Winaya. Pihak pasif ialah para investor.

2. Struktur Organisasi dan Standar Operasional Pekerjaan

Struktur organisasi perusahaan CV. Cantigi ini terdiri atas pemegang sumber dana yaitu para investor yang menanamkan modal dan para pemilik lahan kemudian beberapa penanggung jawab. Kepala bagian langsung bertanggung jawab kepada pimpinan perusahaan Ir. Risa Winaya. Kepengurusan selanjutnya yaitu beberapa orang yang memegang kegiatan dan bertanggung jawab sebagi pengelola yang dapat dilihat pada Gambar 2.

3. Sistem Upah dan Gaji Tenaga Kerja

Gaji untuk seluruh pekerja, kecuali pekerja harian, dibayarkan satu bulan sekali. Pembayaran dapat dilakukan secara transfer ataupun tunai secara langsung kepada para pekerja oleh kepala bagian Administrasi dan Keuangan. Pada pekerja harian, upah akan dibayarkan setiap dua minggu sekali oleh kepala bagian Administrasi dan Keuangan. Adapun besaran gaji yang diberikan kepada masing-masing pekerja sudah ditetapkan

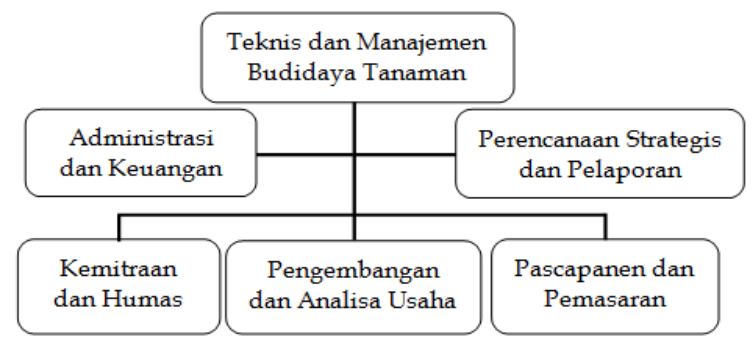

Keterangan :

1. Teknik dan manajemen budidaya tanaman

a. Budidaya, penanggulangan hama/penyakit dan panen.

b. Menentukan semua keputusan di lapangan.

2. Perencanaan strategis dan pelaporan

a. Membuat perencanaan program dalam satu periode tanam (awal tanam-pascapanen-pasar).

b. Membuat pelaporan rutin kondisi usaha.

3. Administrasi dan keuangan

a. Melakukan sistem administrasi.

b. Memanajemen keuangan.

4. Pascapanen dan pemasaran

a. Mencari peluang pasar dan business deal.

b. Packaging dan transportasi.

5. Pengembangan dan analisa usaha

a. Memonitoring dan evaluasi usaha.

b. Mencari peluang usaha strategis serta akses permodalan.

6. Kemitraan dan humas

a. Menjalin mitra usaha dan menterjemahkan program kepada mitra.

b. Menjalin kerjasama dan hubungan baik dengan mitra serta masyarakat sekitar.

\section{Gambar 2. Struktur Organisasi CV.Cantigi}

Sumber: Data Primer, 2019

Berdasarkan analisis aspek manajemen yang telah diuraikan, usahatani selada krop layak untuk dijalankan. Hal tersebut ditunjukkan dengan adanya badan usaha yang mendasari kegiatan usaha berupa CV. Kemudian adanya pembagian wewenang serta tanggung jawab yang jelas, sehingga seluruh pekerjaan dapat dilaksanakan dengan baik.

\section{Aspek Sosial, Ekonomi, Budaya}

Produksi selada krop yang dilakukan perusahaan, khususnya dengan berdirinya CV. Cantigi ini memberikan dampak yang positif bagi kehidupan sosial masyarakat. Hal tersebut dikarenakan perusahaan mempekerjakan masyarakat sekitar untuk ikut serta dalam budidaya selada 
krop dan juga komoditas lainnya yang dibudidayakan CV. Cantigi. Dengan demikian, perusahaan mampu memberikan lapangan pekerjaan bagi masyarakat sekitar. Penyerapan tenaga tersebut memberikan dampak positif terhadap kondisi perekonomian masyarakat sekitar.

Dilihat dari aspek budaya, usaha yang dijalankan CV. Cantigi ini dinilai tidak berpengaruh negatif dengan budaya setempat. Keberadaan usaha ini membantu memberikan pengetahuan kepada masyarakat mengenai teknologi dalam dunia pertanian.

\section{Aspek Lingkungan}

Usaha budidaya selada krop ini tidak memberikan dampak negatif terhadap lingkungan sekitar. Limbah produksi pada budidaya selada krop berupa plastik mulsa yang sudah tidak digunakan kembali. Limbah plastik mulsa tersebut tidak dipergunakan kembali karena telah habis masa produktif atau terkontaminasi. Penanganan limbah pun sudah diperhitungkan dengan adanya kerjasama dengan dinas kebersihan, sehingga lingkungan sekitar lokasi usaha tetap terkendali.

Berdasarkan hasil analisis diatas, dapat dikatakan usahatani selada krop layak untuk dijalankan. Hal tersebut dikarenakan keberadaan usaha ini telah membantu menjaga kebersihan lingkungan sekitar dengan adanya penanganan limbah usahatani.

\section{ANALISIS ASPEK FINANSIAL BUDIDAYA SELADA KROP DI CV.CANTIGI}

Analisis kelayakan finansial dilakukan guna melihat bahwa suatu usaha secara finansial sudah layak atau tidak layak. Analisis ini menggunakan perhitungan dengan kriteria investasi ialah NPV, IRR, Net B/C, PP, dan PR. Hasil perhitungan dapat dilihat pada Tabel 6 berikut.

\section{Net Present Value (NPV)}

Dilihat dari hasil perhitungan, nilai NPV yang diperoleh pada usahatani selada krop sebesar Rp286.076.736,8. Dengan demikian, dilihat dari kriteria investasi NPV, usahatani selada krop layak dijalankan karena nilai NPV yang diperoleh lebih besar dari nol.

\section{Internal Rate of Return (IRR)}

Internal Rate of Return merupakan kriteria investasi yang mana nilainya harus dibandingkan dengan nilai opportunity cost of capital (OCC). Adapun nilai opportunity cost of capital dalam perhitungan ini yang digunakan ialah 16,5 persen. Hasil perhitungan IRR pada cashflow usahatani selada krop menghasilkan sebesar 51,87 persen. Nilai tersebut mengartikan bahwa tingkat pengembalian usaha terhadap setiap satuan modal yang diinvestasikan sebesar 51,87 persen. Hal tersebut menunjukan bahwa nilai IRR lebih besar dari nilai OCC. Sehingga dilihat dari nilai tersebut dapat mengartikan bahwa usahatani selada krop layak untuk dijalankan.

\section{Net Benefit Cost Ratio (Net B/C)}

Net Benefit Cost Ratio merupakan perhitungan yang menunjukan nilai perbandingan antara manfaat bersih positif dengan manfaat bersih negatif. Nilai dari Net B/C yang diperoleh pada usahatani selada krop sebesar 4,32, yang mengartikan bahwa setiap tambahan biaya sebesar Rp1,00 akan memperoleh tambahan manfaat bersih sebesar Rp4,32. Nilai Net B/C yang diperoleh lebih besar dari satu, sehingga dapat dikatakan bahwa usahatani selada krop ini layak untuk dijalankan.

\section{Payback Period (PP)}

Perhitungan kriteria investasi payback period dilakukan guna melihat jangka waktu

Tabel 6. Hasil Analisis Aspek Finansial

\begin{tabular}{lrrr}
\hline \multicolumn{1}{c}{ Kriteria Investasi } & \multicolumn{1}{c}{ Nilai } & Indikator Kelayakan & Hasil Kelayakan \\
\hline NPV & Rp286.076.736,8 & $>0$ & Layak \\
IRR & $51,87 \%$ & $>$ Persentase biaya modal & Layak \\
Net B/C & 4,32 & $>1$ & Layak \\
PAYBACK PERIOD & 8,823 & $<$ umur usaha & Layak \\
Profitability Ratio & $101,78 \%$ & $>$ suku bunga deposito & Layak \\
\hline
\end{tabular}

Sumber: Badan Pusat Statistika (2019) 
pengembalian modal, yang mana nilainya akan dibandingkan dengan umur usaha. Nilai PP yang diperoleh pada usahatani selada krop ialah selama 8 tahun 8 bulan 23 hari. Nilai tersebut menunjukkan bahwa dalam waktu 8 tahun 8 bulan 23 hari seluruh biaya investasi telah kembali. Hal tersebut menunjukkan bahwa jangka waktu pengembalian modal pada usahatani selada krop cukup cepat dari umur usaha. Oleh karenanya, berdasarkan kriteria payback period usahatani selada krop layak untuk dijalankan.

\section{Profitability Ratio (PR)}

Profitability Ratio (PR) merupakan perhitungan dalam kriteria investasi yang digunakan guna mengukur rentabilitas suatu usaha. Berdasarkan hasil perhitungan, nilai PR dalam usahatani selada krop ialah sebesar 101,78\%. Hasil tersebut menunjukkan bahwa usahatani tersebut sangat layak dan sangat menguntungkan karena profitabilitas lebih dari suku bunga bank deposito.

\section{SIMPULAN DAN SARAN}

\section{SIMPULAN}

penelitian ini ialah sebagai berikut hasil analisis pendapatan usahatani selada krop di CV. Cantigi per musim tanam yaitu sebesar Rp120.821.846. Berdasakan aspek non-finansial, usahatani selada krop di CV. Cantigi layak untuk diusahakan. Begitu pula secara finansial, usahatani selada krop di CV. Cantigi layak diusahakan dilihat berdasarkan kriteria investasinya. Usahatani selada krop di CV. Cantigi layak diusahakan dengan nilai NPV Rp286.076.736,8; nilai IRR ialah 51,87\%; Net B/C ialah 4,32; Payback Period 8 tahun 8 bulan, dan Profitability Ratio 101,78\%.

\section{SARAN}

Untuk itu peneliti merekomendasikan saran dalam meningkatkan jumlah hasil produksi selada krop serta keberlanjutan usaha di CV. Cantigi, diperlukan adanya penelitian lebih lanjut mengenai faktor produksi lainya yang dapat dimaksimalkan.

\section{DAFTAR PUSTAKA}

Ambarsari, W., V. D. Y. B Ismadi dan A. Setiadi. (2014). Analisis Pendapatan dan Profitabilitas Usahatani Padi (Oryza sativa) di Kabupaten Indramayu. Jurnal Agri Wiralodra. 6 (2): 19-27.

[BPS] Badan Pusat Statistik. 2016. Statistika Indonesia. Badan Pusat Statistik. Jakarta.

[BPS] Badan Pusat Statistika. 2019. Statistika Indonesia. Badan Pusat Statistika. Jakarta.

Husnan, S. Suwarsono. (1994). Studi Kelayakan Proyek. Yogyakarta: UPP AMP YKPN.

Kasmir. (2014). Analisis Laporan Keuangan. Edisi Satu. Cetakan Ketujuh. Jakarta: PT. Raja Grafindo Persada.

Rukmana, Rahmat. (1994). Bertanam Selada \& Andewi. Yogyakarta: Kanisius.

Soekartawi. (1996). Ilmu Usahatani dan Penelitian Untuk Pengembangan Pertanian Kecil. Jakarta: Rajawali Press. 